\title{
Complex lacustrine ecosystems after the end-Permian mass extinction
}

Bo WANG ${ }^{1 *}$, XIANGDONG ZHAO ${ }^{1,2}$ AND DARAN ZHENG ${ }^{1,3}$

${ }^{1}$ State Key Laboratory of Palaeobiology and Stratigraphy, Nanjing Institute of Geology and Palaeontology and Center for Excellence in Life and Paleoenvironment, Chinese Academy of Sciences, Nanjing 210008, China (*correspondence: bowang@nigpas.ac.cn)

${ }^{2}$ University of Science and Technology of China, Hefei 230026, China.

${ }^{3}$ Department of Earth Sciences, The University of Hong Kong, Hong Kong Special Administrative Region, China.

The end-Permian mass extinction (EPME) led to profound changes in lacustrine ecosystems. The postextinction recovery of lacustrine ecosystems is thought to have been much delayed due to the rarity of Early and Middle Triassic deep perennial lakes. Here we report on mid-Middle Triassic lacustrine organic-rich shales with abundant fossils and tuff interlayers in the Ordos Basin of China, dated to approximately $242 \mathrm{Ma}$. The organic-rich sediments record the earliest known appearance of a deep perennial lake after the mass extinction. The diverse fossil assemblage in the organicrich sediments documents a Mesozoic-type, trophically multilevelled lacustrine ecosystem, supported by a generally oxic to dysoxic, highly productive lacustrine environment. The results reveal the earliest known Triassic complex lacustrine ecosystem after the EPME and suggest that Triassic lacustrine ecosystems took at most 10 million years to recover fully, which is consistent with termination of the 'coal gap' that signifies substantial restoration of peat-forming forests. 